\title{
Capsular Contracture In Silicone Breast Implants: Insights From Rat Models
}

\author{
VILBERTO J. VIEIRA ${ }^{1}$, ARMANDO D'ACAMPORA ${ }^{1}$, FERNANDA S. NEVES ${ }^{2}$, PAULO R. MENDES ${ }^{3}$, \\ ZULMAR A. DE VASCONCELLOS ${ }^{3}$, RODRIGO D'EÇA NEVES ${ }^{3}$ and CLAUDIA P. FIGUEIREDO ${ }^{2}$
}

\author{
${ }^{1}$ Programa de Pós-Graduação em Ciências Médicas, Centro de Ciências da Saúde, Universidade Federal de Santa Catarina, \\ Rua Prof. Maria Flora Pausewang, s/n, Campus Universitário, Trindade, 88040-970 Florianópolis, SC, Brasil \\ ${ }^{2}$ Faculdade de Farmácia, Universidade Federal do Rio de Janeiro, Av. Carlos \\ Chagas Filho, 373, 21941-902 Rio de Janeiro, RJ, Brasil \\ ${ }^{3}$ Serviço de Cirurgia Plástica e Queimados do Hospital Universitário, Universidade Federal de Santa Catarina, Rua \\ Prof. Maria Flora Pausewang, s/n, Campus Universitário, Trindade, 88040-970 Florianópolis, SC, Brasil
}

Manuscript received on December 10, 2015; accepted for publication on February 4, 2016

\begin{abstract}
Breast augmentation with silicone implants is one of the most common procedures performed by plastic surgeons around the world. Capsular contracture is a frequent complication in breast augmentation and reconstructive surgery, that requires invasive intervention. The inflammatory response to implanted mammary prostheses appears to be directly associated to capsular contracture. This review discusses the evidences from rat models studies, on the role of inflammation and fibrosis in capsular contraction and its relation to silicone breast implants surface.
\end{abstract}

Key words: capsular contracture, silicone breast implant, breast augmentation, smooth silicone implants, textured silicone implants, polyurethane-coated silicone implants.

\section{INTRODUCTION}

Plastic surgery had robust advances in the last decades, with the development of new surgical techniques and new materials used as substitutes of organs and tissues. Breast augmentation with silicone implants is one of the most common procedures performed by plastic surgeons in the world (Sukhova et al. 2012). Few medical materials were studied on their safety as rigorously as the silicone gel implants (Barnsley et al. 2006, Gampper et al. 2007, Spear et al. 2006). Silicone has been widely used in many areas of medicine

Correspondence to: Claudia Pinto Figueiredo

E-mail: claufig@gmail.com demonstrating its biosafety and biocompatibility (Sukhova et al. 2012, Barnsley et al. 2006).

Czerny (1895) described the first breast augmentation procedure when reported the transplantation of a giant lipoma to the breast (Czerny 1895, Spear et al. 2009). There were numerous unsuccessful attempts of breast augmentation with both alloplastic and autologous tissue since then (Gersuny 1980, Thorek 1942, Harris 1961, Lalardrie and Mouly 1978, Rubin 1951, Edgerton and Mc 1958, Demergian 1963, Calnan 1970, Smahel et al. 1977). Silicone implants were first introduced in 1963 by Cronin and Gerow (Cronin and Gerow 1963), starting the modern era of breast augmentation (Young and Watson 2001, Adams 2009a, Spear et al. 2009). 
Five different generations of silicone implants have been developed (Maxwell and Gabriel 2009, Pitanguy 1991), as demonstrated in Table I.

The first generation of implants (1962-1970) was characterized by a dense and viscous silicone gel, surrounded by a thick, smooth implant shell. Second generation (1970-1982) was rounder, with less cross-linked gels (less viscous) covered by a smooth, thinner and slightly permeable shell (Calobrace and Capizzi 2014). In order to reduce capsular contracture, third generation implants (1982-1992) came with a more viscous gel and thicker either smooth or textured shell, and a less permeable low-bleeding elastomer barrier (Maxwell and Gabriel 2009). When the textured surface came up, the fourth-generation devices arised (1993 to present) (Adams 2009a). Texturing of implant surface was due to the experience with polyurethane (PU)-coated foam implants, which indicated that rough implants resulted in lower capsular contracture rates. Finally, cohesive silicone gel-filled implants can be considered fifthgeneration devices (Adams 2009a, Maxwell and Gabriel 2009) (Table I). The updates in progressive generations have correlated with a decreased incidence in capsular contracture, although it is not clear if this is entirely because of implant design (Bengtson et al. 2007, Cunningham 2007, Danino et al. 2001).

Besides the evolution of silicone implants and surgical procedures, breast augmentation is still associated with complications such as hematoma, seroma, infection, rupture, silicone leakage, changes in mammary sensitivity, chronic pain, poor positioning, wrinkling skin, and capsular contracture (Barnsley et al. 2006, Spear et al. 2006, Thorek 1942., Harris 1961, Lalardrie and Mouly 1978, Garcia et al. 2002, Edgerton and Mc 1958, Demergian 1963, Calnan 1970). Capsular contracture is the formation of a fibrous scar tissue that surrounds a foreign body or surgically implanted device (Adams et al. 2006). Artificial

TABLE I

Evolution of silicone gel-filled breast implants.

\begin{tabular}{|c|c|c|}
\hline Implant Generation & Period & Characteristics \\
\hline \multirow{4}{*}{ First Generation } & \multirow{4}{*}{$1962-1970$} & Thick, two-piece shell \\
\hline & & Smooth surface \\
\hline & & Anatomically-shaped (teardrop) \\
\hline & & Viscous silicone gel \\
\hline \multirow{4}{*}{ Second Generation } & \multirow{4}{*}{$1970-1982$} & Thin, slightly permeable shell \\
\hline & & Smooth surface \\
\hline & & Round shape \\
\hline & & Less viscous silicone gel \\
\hline \multirow{4}{*}{ Third Generation } & \multirow{4}{*}{ 1982-1992 } & Thick, strong, low-bleed shell \\
\hline & & Smooth surface \\
\hline & & Round shape \\
\hline & & More viscous silicone gel \\
\hline \multirow{4}{*}{ Fourth Generation } & \multirow{4}{*}{ 1993-present } & Thick, strong, low-bleed shell \\
\hline & & Smooth and textured surfaces \\
\hline & & Round and anatomically-shaped \\
\hline & & More viscous (cohesive) silicone gel \\
\hline \multirow{4}{*}{ Fifth Generation } & \multirow{4}{*}{ 1993-present } & Thick, strong, low-bleed shell \\
\hline & & Smooth and textured surfaces \\
\hline & & Round and diverse anatomical shapes \\
\hline & & Enhanced cohesive and stable gel \\
\hline
\end{tabular}


joints, heart valves, central venous catheter ports, breast implants, and many additional medical devices have been involved in capsule formation and its adverse consequences (Adams et al. 2006). Capsule formation plays an important role in the host response against a foreign body. Therefore, the outcome of this process may pose a serious health risk and/or aesthetic sequelae (Adams et al. 2006). Mammary prostheses can induce inflammatory responses, periprosthetic fibrous capsule formation and implant encapsulation. Eventually, if capsular contracture occurs another surgical intervention is required for implant removal (Balderrama et al. 2009). Capsular contracture remains one of the most common complication and a leading cause for patient dissatisfaction of both aesthetic and reconstructive breast implant surgery (Lee et al. 2014, Wong et al. 2006).

Predisposition to hypertrophic scar and declining age have been associated to capsular contracture, hematoma and silicone gel bleed (Adams 2009b, Vieira et al. 2010). Several studies also evidence the link between subclinical infection and capsular contracture occurrence (Bergmann et al. 2014, Del Pozo et al. 2009, Dobke et al. 1995). In the same line, many studies support that bacterial biofilms on breast implants, most commonly formed by Staphylococcus epidermidis, can promote chronic inflammation, and stimulate fibrosis and capsular contracture (Rieger et al. 2013, van Heerden et al. 2009, Dobke et al. 1995, Netscher 2004). Del Pozo et al. (2009), in a prospective observational assay verified bacterial infection in breast prostheses from 45 patients who underwent implant removal for reasons other than overt infection. The results reveal a significant association between capsular contracture and the presence of skin flora bacterias on the implant (Del Pozo et al. 2009). Recently, Bergmann et al. (2014) used a rat model to evaluate the influence of controlled infection in capsular formation around PU-coated silicone implants, and demonstrated that both implant surface and bacterial contamination impact the architecture of capsule formation (Bergmann et al. 2014). This approach showed that bacterial infection leads to thicker capsules with increased inflammatory response evidenced by the higher amount of inflammatory cells within the tissue (Tables II and III) (Bergmann et al. 2014). However, Mendes et al. (2008) also using a rat model, observed no relationship between Staphylococcus epidermidis infection and capsular architecture (Table II and III) (Mendes et al. 2008). Therefore, the possible relationship of bacterial infection and capsular contracture occurrence needs further study.

Many studies are committed in unveiling not only the causes but also the possible preventive strategies to capsular contracture (Moreira et al. 2009, Poeppl et al. 2007, Ibrahim Canter et al. 2007, Bern et al. 1992, Vieira et al. 2010, Adams et al. 2006). As showed in Table I, silicone implants underwent several structural adjustments in the last decades in order to diminish foreign body reaction and consequently reduce capsular contraction incidence (Balderrama et al. 2009). Among other modifications, smooth surface implants were replaced by textured linings or PU-coating (Lyras 1993). However, despite these changes in implant surface being reported by many authors as crucial in reducing capsular contracture, this approach is controversial (Pollock 1997, Spear et al. 2000, Ersek 1991). The real cause of capsular contracture remains elusive (Rohrich et al. 1999). This review discusses the evidences obtained from rat models of silicone breast implants, on the role of inflammation and fibrosis in capsular contraction pathogenesis and their relation to the silicone prosthesis surface.

EXPERIMENTAL RAT MODELS FOR CAPSULAR CONTRACTURE STUDY

Numerous experimental studies have attempted to identify the reason behind the lower rates of capsular contracture in textured surface implants. These 
TABLE II

Summary of experimental approaches used to study capsular contracture after implantation of silicone mini-prostheses in rats.

\begin{tabular}{lll}
\hline Reference & Title & Study Design \\
\hline
\end{tabular}

Animals: 32 adult female Wistar rats.

"Histologic analysis of

Bastos et al. 2007 zafirlukast's effect on capsule formation around silicone implants".
Groups: 3 groups that received both smooth and textured surface silicone mini-implant.

Intervention: Intraperitoneal treatment with either vehicle or zafirlukast (1.25 or $5 \mathrm{mg} / \mathrm{kg} /$ day; for 90 days).

Follow up: 90 days.

Capsular evaluation: Histological (HE, trichrome and picrosirius red stain), and immunohistochemistry (anti- $\alpha$-SMA antibody) analyses.

Animals: 40 adult female Wistar rats.

Groups: 4 groups that received both smooth and textured surface silicone mini-implant.

"Effect of zafirlukast on

Bastos et al. 2012 capsular contracture around Intervention: Intraperitoneal treatment with either zafirlukast (1.25 mg/kg/ silicone implants in rats". day; during 90 days) or vehicle.

Follow up: 90 days.

Capsular evaluation: Intra-implant pressure measurement.

Animals: 80 adult female Wistar rats.
"The effect of a bacterial contamination on the formation of capsular

Bergmann et al. 2014 contracture with polyurethane breast implants in comparison with textured silicone implants: an animal study".
Groups: 4 groups that received either textured surface or PU-coated silicone mini-implant.

Intervention: Implant inoculation with vehicle or a standard volume of Staphylococcus epidermidis.

Follow up: 60 days.

Capsular evaluation: Histological (HE, trichrome, naphthol-ASDacetatesterase and picrosirius red stain), immunohistochemistry (anti-CD3, anti-CD138, anti-Lysozyme, anti-Pax 5 and anti- $\alpha$-SMA antibodies), and microbiological analyses.

$\begin{array}{ll}\text { Cardenas- } & \begin{array}{l}\text { "Electrostimulation: } \\ \text { uses and applications for } \\ \text { Camarena et al. }\end{array} \\ 2005 & \begin{array}{l}\text { periprosthetic capsular } \\ \text { contracture: experimental } \\ \text { model". }\end{array}\end{array}$

Gancedo et al. 2008

\section{Animals: 40 adult female Wistar rats;}

Groups: 10 groups that received both smooth and textured surface silicone min-implant.

Intervention: Different protocols of local electrostimulation from the 3rd to the 15 th postoperative day.

Follow up: 16 days;

Capsular evaluation: Histological (HE) analyses.
Animals: 20 adult female Wistar rats.

Groups: 2 groups that received both smooth and textured surface silicone mini-implant.

Intervention: Intraperitoneal treatment with vehicle or Pirfenidone (PFD) (200 mg/Kg/day, for 60 days).

Follow up: 60 days.

Capsular evaluation: Histological (HE, trichrome, picrosirius red stain), immunohistochemistry (anti-TGF- $\beta 1$, anti- $\alpha$-SMA antibodies), and real-time PCR (TGF- $\beta$ and collagen $\alpha$ I) analyses.

Animals: 35 adult female Wistar rats.

Groups: 7 groups that received PU-coated silicone mini-implant.

"Histological study on acute

Mendes et al. inflammatory reaction to

Intervention: Contamination of implant cavity with $10^{1}, 10^{3}$, or $10^{5}$ bacteria/ polyurethane-coated silicone $\mathrm{mL}$ with implant immersions in anti-microbial solution or saline. implants in rats".

Follow up: 30 days.

Capsular evaluation: Histological (HE and picrosirius red stain) analyses. 
TABLE II (continuation)

\begin{tabular}{|c|c|c|}
\hline Reference & Title & Study Design \\
\hline \multirow{5}{*}{ Vieira et al. 2010} & \multirow{5}{*}{$\begin{array}{l}\text { "Vascular endothelial } \\
\text { growth factor overexpression } \\
\text { positively modulates } \\
\text { the characteristics of } \\
\text { periprosthetic tissue of } \\
\text { polyurethane-coated silicone } \\
\text { breast implant in rats". }\end{array}$} & Animals: 34 adult female Wistar rats. \\
\hline & & $\begin{array}{l}\text { Groups: } 4 \text { groups that received textured surface or PU-coated silicone mini- } \\
\text { implant. }\end{array}$ \\
\hline & & Intervention: no intervention. \\
\hline & & Follow up: 30 and 60 days. \\
\hline & & $\begin{array}{l}\text { Capsular evaluation: Histological (HE, trichrome, picrosirius red stain), } \\
\text { immunohistochemistry (anti-VEGF, anti-TGF- } \beta 1 \text {, anti- } \alpha \text {-SMA, and anti- } \\
\text { MPX antibodies) analysis. }\end{array}$ \\
\hline \multirow{5}{*}{$\begin{array}{l}\text { Zimman et al. } \\
2007\end{array}$} & \multirow{5}{*}{$\begin{array}{l}\text { "The effects of angiotensin- } \\
\text { converting-enzyme } \\
\text { inhibitors on the fibrous } \\
\text { envelope around mammary } \\
\text { implants". }\end{array}$} & Animals: 24 adult female Wistar rats. \\
\hline & & $\begin{array}{l}\text { Groups: } 4 \text { groups that received either smooth or textured surface silicone } \\
\text { mini-implants. }\end{array}$ \\
\hline & & $\begin{array}{l}\text { Intervention: angiotensin-converting enzyme inhibitor enalapril } \\
\text { administered in drinking water, ad libitum. }\end{array}$ \\
\hline & & Follow up: 90 days. \\
\hline & & $\begin{array}{l}\text { Capsular evaluation: Histological (HE, trichrome, picrosirius red stain), and } \\
\text { immunohistochemistry (anti-TGF- } \beta 1 \text { and anti-collagen type III antibodies) } \\
\text { analysis. }\end{array}$ \\
\hline
\end{tabular}

HE (Hematoxylin-eosine); MPX (myeloperoxidase); Pax5 (paired box protein 5); PU (polyurethane); TGF- $\beta 1$ (transforming growth factor beta 1); VEGF (vascular endothelial grown factor); $\alpha$-SMA (alpha smooth muscle actin).

TABLE III

Summary of conclusions from capsular contracture studies after implantation of silicone mini-prostheses in rats.

\begin{tabular}{|c|c|}
\hline Reference & Conclusions \\
\hline Bastos et al. 2007 & $\begin{array}{l}\text { Systemic leukotriene receptor antagonist (Zafirlukast) treatment reduced inflammatory parameters, } \\
\text { myofibroblasts, collagen density and capsular thickness in periprosthetic tissue of animals with textured } \\
\text { surface silicone prostheses. Treatment with leukotriene antagonist had no effect in capsular tissue of } \\
\text { smooth silicone implants. }\end{array}$ \\
\hline Bastos et al. 2012 & $\begin{array}{l}\text { Systemic Zafirlukast treatment reduces capsular contracture-related factors, surrounding textured silicone } \\
\text { implants only. Results suggest that smooth and textured surface silicone prostheses have different } \\
\text { mechanisms to induce capsular contracture. }\end{array}$ \\
\hline Bergmann et al. 2014 & $\begin{array}{l}\text { Bacterial infection induces thicker capsule formation and increases inflammatory response. PU-coated } \\
\text { implants drives thicker capsule formation and intense local inflammatory processes when compared to } \\
\text { textured implants. However, periprosthetic tissue surrounding PU implants showed lower expression of } \\
\text { parallel myofibrils. }\end{array}$ \\
\hline $\begin{array}{l}\text { Cardenas-Camarena } \\
\text { et al. } 2005\end{array}$ & $\begin{array}{l}\text { Local electrostimulation regulates periprosthetic capsule formation in both textured and smooth surface } \\
\text { silicone prostheses when transplanted into rats. }\end{array}$ \\
\hline Gancedo et al. 2008 & $\begin{array}{l}\text { Systemic treatment with Pirfenidone (PFD), an anti-fibrotic drug used for pulmonary fibrosis, } \\
\text { decreases inflammation, TGF- } \beta 1 \text { levels, and capsular thickness, compared with vehicle-treated animals. } \\
\text { Histological analysis shows no differences between textured and smooth periprosthetic tissue. }\end{array}$ \\
\hline Mendes et al. 2008 & $\begin{array}{l}\text { PU-coated silicone implants induce inflammatory response in periprosthetic tissue histologically- } \\
\text { patterned as chronic foreign body granulomas. Histological changes induced by Staphylococcus } \\
\text { epidermidis inoculation were dose-independent. }\end{array}$ \\
\hline Vieira et al. 2010 & $\begin{array}{l}\text { Periprosthetic tissue of PU-coated silicone implants was thicker and showed intense vascularization and } \\
\text { inflammatory response, compared with textured implants. In addition, PU-coated implants had a softer } \\
\text { capsule and increased VEGF and TGF- } \beta 1 \text { levels in capsular tissue than textured surface prostheses. }\end{array}$ \\
\hline Zimman et al. 2007 & $\begin{array}{l}\text { Systemic enalapril treatment reduced inflammatory and fibrotic processes in the periprostethic tissue } \\
\text { from both textured and smooth surface silicone implants. }\end{array}$ \\
\hline
\end{tabular}

PU (polyurethane); TGF- $\beta 1$ (transforming growth factor-beta 1); VEGF (vascular endothelial growth factor). 
studies have used animal models with smooth or textured prostheses implanted both subcutaneously and submuscularly, with subsequently histological evaluation of the neo-formed periprosthetic tissue (Barone et al. 1992, Bucky et al. 1994, Bern et al. 1992, Clugston et al. 1994, Brohim et al. 1993b). Importantly, some studies found tighter and thicker capsules surrounding textured implants compared to smooth implants (Barone et al. 1992, Bucky et al. 1994, Bern et al. 1992), while others demonstrated that capsular contracture is less often in textured surface implants (Clugston et al. 1994, Brohim et al. 1993b).

Despite these ambiguous results, miscellaneous of clinical data on capsular contracture incidence in patients (Barnsley et al. 2006), highlights the relevance of controlled experimental models to study capsular contracture etiology and many assays rely on animal models to mimic human periprosthetic capsular contracture (Barnsley et al. 2006, Wong et al. 2006, Vieira et al. 2010). Preclinical benchwork advantages include the control of the experimental environment, minimizing unwanted variables, besides being a faster, less expensive approach (Bastos et al. 2003, Bucky et al. 1994, Clugston et al. 1994, Imber et al. 1974, Ksander et al. 1981, Peters et al. 1980, Vieira et al. 2010). Animals such as pigs, rabbits, dogs, rats, and mice have been used with variable results (Clugston et al. 1994, Fagrell et al. 2001, Ajmal et al. 2003, Shah et al. 1981, Kossovsky et al. 1984, Chen et al. 1996, Darouiche et al. 2002, Ksander et al. 1981, Tang et al. 1998, Adams et al. 2006, Marques et al. 2012, Brohim et al. 1993a, Minami et al. 2006, Park et al. 2013, Moyer et al. 2012, Bastos et al. 2003, 2012), but it is consensus that the rat is the most appropriate animal model that provides relevant scientific conclusions with accurate histological extrapolation to the human tissue (Czerny 1895b, Harris 1961, Lalardrie and Mouly 1978, Garcia et al. 2002). In addition, most studies agree that a 90 -days follow up seems to be suitable to evaluate capsular contracture in rats (Tables II and III). The main approaches tested in the studies reviewed in Tables II and III were the effects of smooth and/or textured silicone implants on different histological and biochemical parameters (Zimman et al. 2007, Vieira et al. 2010, Mendes et al. 2008, Gancedo et al. 2008, Cardenas-Camarena et al. 2005, Bergmann et al. 2014, Bastos et al. 2007b, 2012). The results indicate different degrees of fibrosis, fibroblast activation, inflammation, and capsule thickness in periprosthetic tissue (Tables II and III) (Frangou and Kanellaki 2001, Eltze et al. 2003, Minami et al. 2006, Eltze et al. 2006, Adams et al. 2006, Cardenas-Camarena et al. 2005, Gancedo et al. 2008, Chelko et al. 2012, Aparecida da Silva et al. 2014, Vieira et al. 2010). Some authors did not find histological differences between smooth and textured implants surrounding tissue (Gancedo et al. 2008), but most found thicker capsules with increased cellularity and less frequent contractures in the textured surface (Bastos et al. 2007a, 2012, Zimman et al. 2007, Cardenas-Camarena et al. 2005, Bergmann et al. 2014) (Tables II and III). There are some studies with rabbits trying to understand the capsular contracture process, but interestingly, most of them use smooth surface mini-implants only (Shin et al. 2013, Park et al. 2013, Moyer et al. 2012, Adams et al. 2006). To our knowledge, a single rabbit study compared textured and smooth surface silicone mini-implant, and found less cellularity and reduced capsule thickness surrounding textured surface prostheses (Uzunismail et al. 2008). Minami et al. (2006) used pigs to show that capsular contracture in smooth implants have a significantly higher intra-implant pressure, and the smooth implant capsule was significantly thicker than the textured (Minami et al. 2006).

Considering that prevention of capsular contracture is a relevant clinical approach, various experimental designs using rats as model have been conducted aiming to identify potential pharmacological targets to achieve that goal, testing 
different implant materials (i.e. textured, smooth or PU-covered) (Chang et al. 1992, Ersek 1991, Hester et al. 1988, Asplund et al. 1996, Thuesen et al. 1995), surgical procedures (i.e. subglandular or submuscular pockets) (Puckett et al. 1987, Hakelius and Ohlsen 1997, Handel et al. 1995), and drug delivery systems (Ajmal et al. 2003, Lemperle and Exner 1993). Tables II and III show some studies that evaluated the effect of angiotensinconverting enzyme inhibitors (Zimman et al. 2007), leukotriene receptor antagonist (zafirlukast) (Bastos et al. 2007b, Bastos et al. 2012), and antifibrotic compound (pirfenidone) (Gancedo et al. 2008) on biochemical and cellular features of periprosthetic tissue from rats that received smooth or textured silicone implants (Bastos et al. 2007b, 2012, Gancedo et al. 2008, Zimman 2007). Bastos et al. (2012) also tested the effects of Zafirlukast on intra-implant pressure after implantation of both textured and smooth silicone implant in rats, and concluded that treatment increases internal pressure only in textured silicone implants (Tables II and III). Finally, these distinct pharmacological outcomes on capsular prevention strengthen the concept that capsular contracture pathophysiology is prosthesis type-dependent (Bastos et al. 2007b, 2012, Gancedo et al. 2008, Zimman 2007, Bergmann et al. 2012, 2014).

Our previous study on the characteristics of periprosthetic tissue surrounding textured surface silicone implants in rats demonstrated that PUcoated implants induce thicker capsules, associated to intense "foreign body" immune reaction and upregulation of vascular endothelial growth factor (VEGF) (Vieira et al. 2010). We propose that high vascularization induced by VEGF results in this thicker capsule, but capsular enlargement would be due to an increase of the non-collagenoustissue layer. Furthermore, we concluded that stimulation of an angiogenic response in periprosthetic tissue leads to a softer capsule surrounding the silicone implant, which should decrease capsular contracture occurrence in breast reconstruction and augmentation (Vieira et al. 2010). Consistent with our findings, other studies also hypothesized that the positive effects of PU implants on capsular prevention are mainly related to the biochemical effects of the biomaterial in the surrounding tissue rather than the prosthesis surface texture itself (Adams 2009a, Hester et al. 1988, 2001, Lilla and Vistes 1976, Brand 1984, Dunn et al. 1992, Brohim et al. 1992, Batra et al. 1995, Picha and Goldstein 1991, Picha et al. 1990, Sank et al. 1993, Santere et al. 2005, Bucky et al. 1994, Rebello 1996).

\section{CONCLUSIONS}

Capsular contracture is a multifactorial process involving inflammatory responses that results in exacerbated fibrotic reaction in silicone breast implant surrounding tissue. However, both the precise trigger and the mechanisms underlying capsular contracture are still unclear. Several animal models have been described in order to approach normal capsular formation, but the origin of capsular contracture can hardly be predicted and the mechanisms concerning pathological capsule formation have yet to be evaluated in these models.

Some animals such as rabbits, pigs andmice have been used with variable results, but it is consensus that rats provide a reproducible and relatively cheap model with accurate histologic extrapolation to human tissue. The results of numerous experimental approaches have shown variations in capsule thickness with different intensities of fibrosis and inflammation in periprosthetic tissue of both textured and smooth silicone implants. Contradictory experimental findings, at least in part, may be due to characteristics of implant manufacturer, consistency of the silicone gel, shape of the implants, (Minami et al. 2006, Calobrace and Capizzi 2014, Adams 2009a, Kjoller et al. 2001, Henriksen et al. 2005, Steiert et al. 2013), size of the pores, type of elastomer surface (Brohim et al. 1992), and/or relatively short observation windows 
(Minami et al. 2006, Clugston et al. 1994). Herein, we showed that the mean follow up used in most assays is 90 days. Therefore, long-term studies using rat models might be necessary to translational conclusions, especially if one considers that 15 years of follow up in a female human being is comparable to approximately 9 months in rat models (Vieira et al. 2010).

In addition, since experimental models are rarely able to replicate the development of capsular contracture, most studies evaluate the outcome of different interventions on normal capsule formation in their animal models (Vieira et al. 2010, Dobke et al. 1995, Rieger et al. 2013, Bastos et al. 2003, 2007a, Imber et al. 1974, Ksander et al. 1981, Peters et al. 1980, Chelko et al. 2012, Aparecida da Silva et al. 2014, Shin et al. 2013, Uzunismail et al. 2008, Chang et al. 1992, Hester et al. 1988, Asplund et al. 1996, Thuesen et al. 1995, Puckett et al. 1987, Hakelius and Ohlsen 1997, Handel et al. 1995, Lemperle and Exner 1993, Zimman 2007, Zimman et al. 2007, Bergmann et al. 2012, Hester et al. 2001, Lilla and Vistes 1976, Brand 1984). This fact understates the impact of conclusions from previous studies, since therapy should be focused in pathologic capsule formation. Some authors evaluated parameters such as liquid infusion and pressure-volume curve or applanation tonometry, beyond the histological analysis to assess capsular contracture in animal models (Bastos et al. 2012, Bucky et al. 1994, Clugston et al. 1994, Peters et al. 1980, Adams et al. 2006, Marques et al. 2012, Minami et al. 2006, Moyer et al. 2012). These studies contribute to the correlation of capsule histological analysis with dynamic pressure assays advancing our comprehension of capsular contracture. To our knowledge, only eight experimental studies showed indirect presence of the capsular contracture until now (Bastos et al. 2012, Bucky et al. 1994, Clugston et al. 1994, Peters et al. 1980, Adams et al. 2006, Marques et al. 2012, Minami et al. 2006, Moyer et al. 2012).
The translational potential of capsular contracture animal models still needs to be clarified. However, pre-clinical studies enable a more controlled and thorough assessment of the periprosthetic tissue characteristics, which is critical to our understanding on how silicone implant surface interacts with the surrounding tissue. Finally, these advances can open new avenues on implant type selection, and in prevention and/or treatment of symptomatic cases of capsular contracture.

\section{REFERENCES}

ADAMS WP. 2009a. Capsular contracture: what is it? What causes it? How can it be prevented and managed? Clinics in plastic surgery $36: 119-126$.

ADAMS WP. 2009b. Capsular contracture: What is it? What causes it? How can it be prevented and maneged? Clin Plast Surg 36: 119-126.

ADAMS WP, HAYDON MS JR, RANIERE J JR, TROTT S, MARQUES M, FELICIANO M, ROBINSON JB JR, TANG L AND BROWN SA. 2006. A rabbit model for capsular contracture: development and clinical implications. Plast Reconstr Surg 117: 1214-1219.

AJMAL N, RIORDAN CL, CARDWELL N, NANNEY LB AND SHACK RB. 2003. Chemically assisted capsulectomy in the rabbit model: a new approach. Plast Reconstr Surg 112: 1449-1454.

APARECIDA DA SILVA C, MOLINAR MAUAD CINTRA M, CASTRO COBO E, VINICIUS DA SILVA M, BICHUETTE CUSTODIO F, ROSA MIRANDA CORREA R, ROBERTO CASTELLANO L, ANTONIA DOS REIS M AND REIS MACHADO J. 2014. Renal biopsy: use of biomarkers as a tool for the diagnosis of focal segmental glomerulosclerosis. Dis Markers 2014: 192836.

ASPLUND O, GYLBERT L, JURELL G AND WARD C. 1996. Textured or smooth implants for submuscular breast augmentation: a controlled study. Plast Reconstr Surg 97: 1200-1206.

BALDERRAMA CM, RIBAS-FILHO JM, MALAFAIA O, CZECZKO NG, DIETZ UA, SAKAMOTO DG AND BITTENCOURT LP. 2009. Healing reaction to mammary prostheses covered by textured silicone and silicone foam in rats. Acta Cir Bras 24: 367-376.

BARNSLEY GP, SIGURDSON LJ AND BARNSLEY SE. 2006. Textured surface breast implants in the prevention of capsular contracture among breast augmentation patients: a meta-analysis of randomized controlled trials. Plast Reconstr Surg 117: 2182-2190. 
BARONE FE, PERRY L, KELLER T AND MAXWELL GP. 1992. The biomechanical and histopathologic effects of surface texturing with silicone and polyurethane in tissue implantation and expansion. Plast Reconstr Surg 90: 77-86.

BASTOS EM, NETO MS, ALVES MT, GARCIA EB, SANTOS RA, HEINK T, PEREIRA JB AND FERREIRA LM. 2007a. Histologic analysis of zafirlukast's effect on capsule formation around silicone implants. Aesth Plast Surg 31: 559-565.

BASTOS EM, NETO MS, ALVES MTS, GARCIA EB, SANTOS RA, HEINK T, PEREIRA JB AND FERREIRA JM. 2007b. Histologic Analysis of Zafirlukast's Effect on Capsule Formation Around Silicone Implants. Aesth Plast Surg 31: 559-565.

BASTOS ÉM, NETO MS, FERREIRA LM, GARCIA ÉB, LIEBANO RE AND HAN YA. 2003. Experimental Model of capsular contracture in silicone implants. Acta Cir Bras 18: 22-28.

BASTOS EM, SABINO NETO M, GARCIA EB, VEIGA DF, HAN YA, DENADAI R, SANTOS RDE A AND FERREIRA LM. 2012. Effect of zafirlukast on capsular contracture around silicone implants in rats. Acta Cir Bras 27: 1-6.

BATRA M, BERNARD S AND PICHA G. 1995. Histologic comparison of breast implant shells with smooth, foam, and pillar microstructuring in a rat model from 1 day to 6 months. Plast Reconstr Surg 95: 354-363.

BENGTSON BP, VAN NATTA BW AND MURPHY DK. 2007. Style 410 highly cohesive silicone breast implant core study results at 3 years. Plast Reconstr Surg 120: 40S-48S

BERGMANN PA, LIODAKI ME, MAUSS KL, LANGE T, GEBHARD M, MAILANDER P AND SIEMERS F. 2012.

Histological and immunohistochemical study of capsular contracture in an animal model--a comparison of two implants according to a modification of Wilflingseder's classification. Handchir Mikrochir Plast Chir 44: 220-226.

BERGMANN PA, TAMOURIDIS G, LOHMEYER JA, MAUSS KL, BECKER B, KNOBLOCH J, MAILANDER P AND SIEMERS F. 2014. The effect of a bacterial contamination on the formation of capsular contracture with polyurethane breast implants in comparison with textured silicone implants: an animal study. JPRAS 67: 1364-1370.

BERN S, BURD A AND MAY JWJ. 1992. The biophysical and histologic properties of capsules formed by smooth and textured silicone implants in the rabbit. Plast Reconstr Surg 89: 1037-1042.

BRAND G. 1984. Foam-covered mamary implants. Clin Plast Surg 73: 498.

BROHIM RM, FORESMAN PA, GRANT GM, MERICKEL MB AND RODEHEAVER GT. 1993a. Quantitative monitoring of capsular contraction around smooth and textured implants. Ann Plast Surg 30: 424-434.
BROHIM RM, FORESMAN PA, GRANT GM, MERICKEL MB AND RODEHEAVER GT. 1993b. Quantitative monitoring of capsular contraction around smooth and textured implants. Ann Plast Surg 30: 424-434.

BROHIM RM, FORESMAN PA, HILDEBRANDT PK AND RODEHEAVER GT. 1992. Early tissue reaction to textured breast implant surfaces. Ann Plast Surg 28: 354-362.

BUCKY LP, EHRLICH HP, SOHONI S AND MAY JW JR. 1994. The capsule quality of saline-filled smooth silicone, textured silicone, and polyurethane implants in rabbits: a long-term study. Plast Reconstr Surg 93: 1123-1131.

CALNAN JS. 1970. Assessment of biological properties of implants before their clinical use. Proc R Soc Med 63: 1115-1118.

CALOBRACE MB AND CAPIZZI PJ. 2014. The biology and evolution of cohesive gel and shaped implants. Plast Reconstr Surg 134: 6s-11s.

CARDENAS-CAMARENA L, PAILLET JC AND BRISENO R. 2005. Electrostimulation: uses and applications for periprosthetic capsular contracture: experimental model. Aesth Plast Surg 29: 410-414.

CHANG L, CALDWELL E, READING G AND WRAY RC JR. 1992. A comparison of conventional and low-bleed implants in augmentation mammaplasty. Plast Reconstr Surg 89: 79-82.

CHELKO SP, SCHMIEDT CW, LEWIS TH, LEWIS SJ AND ROBERTSON TP. 2012. A novel vascular clip design for the reliable induction of 2-kidney, 1-clip hypertension in the rat. J Appl Physiol 112: 362-366.

CHEN NT, BUTLER PE, HOOPER DC AND MAY JW, JR. 1996. Bacterial growth in saline implants: in vitro and in vivo studies. Ann Plast Surg 36: 337-341.

CLUGSTON PA, PERRY LC, HAMMOND DC AND MAXWELL GP. 1994. A rat model for capsular contracture: the effects of surface texturing. Ann Plast Surg 33: 595-599.

CRONIN TD AND GEROW FJ. 1963. Augmentation mammoplasty:a new natural feel prosthesis. In: Transactions of the Third International Congress of Plastic Surgery, Octuber 13-18, 1963, Amsterdan, p. 41-49.

CUNNINGHAM B. 2007. The Mentor Study on contour profile gel silicone MemoryGel breast implants. Plastic and reconstructive surgery 120 .

CZERNY V. 1895. Plastischer ersatz der brustdru $\square$ se durch ein lipom. Zentralbl Chir 22:72.

DANINO AM, BASMACIOGLU P, SAITO S, ROCHER F, BLANCHET-BARDON C, REVOL M AND SERVANT JM. 2001. Comparison of the capsular response to the Biocell RTV and Mentor 1600 Siltex breast implant surface texturing: a scanning electron microscopic study. Plast Reconstr Surg 108: 2047-2052.

DAROUICHE RO, MEADE R, MANSOURI MD AND NETSCHER DT. 2002. In vivo efficacy of antimicrobe- 
impregnated saline-filled silicone implants. Plast Reconstr Surg 109: 1352-1357.

DEL POZO JL ET AL. 2009. Pilot study of association of bacteria on breast implants with capsular contracture. J Clin Microbiol 47: 1333-1337.

DEMERGIAN V. 1963. EXPERIENCES WITH THE NEWER SUBCUTANEOUS IMPLANT MATERIALS. Surg Clin North Am 43: 1313-1321.

DOBKE MK, SVAHN JK, VASTINE VL, LANDON BN, STEIN PC AND PARSONS CL. 1995. Characterization of microbial presence at the surface of silicone mammary implants. Ann Plast Surg 34: 563-569.

DUNN KW, HALL PN AND KHOO CT. 1992. Breast implant materials: sense and safety. Brit J Plast Surg 45: 315-321.

EDGERTON MT AND MC CA. 1958. Augmentation mammaplasty; psychiatric implications and surgical indications; (with special reference to use of the polyvinyl alcohol sponge ivalon). Plast Reconstr Surg Transplant Bull 21: 279-305.

ELTZE E, BETTENDORF O, RODY A, JACKISCH C, HERCHENRODER F, BOCKER W AND PFLEIDERER B. 2003. Influence of local complications on capsule formation around model implants in a rat model. J Biomed Mater Res A 64: 12-19.

ELTZE E, SCHAFER U, BETTENDORF O, RODY A, HERCHENRODER F, CHIWRITSCH T, JACKISCH C AND PFLEIDERER B. 2006. Radiation-induced capsule tissue reactions around textured breast implants in a rat model. Breast 15: 331-338.

ERSEK RA. 1991. Rate and incidence of capsular contracture: a comparison of smooth and textured silicone doublelumen breast prostheses. Plast Reconstr Surg 87: 879-884.

FAGRELL D, BERGGREN A AND TARPILA E. 2001. Capsular contracture around saline-filled fine textured and smooth mammary implants: a prospective 7.5-year followup. Plast Reconstr Surg 108: 2108-2112.

FRANGOU J AND KANELLAKI M. 2001. The effect of local application of mitomycin-C on the development of capsule around silicone implants in the breast: an experimental study in mice. Aesth Plast Surg 25: 118-128.

GAMPPER TJ, KHOURY H, GOTTLIEB W AND MORGAN RF. 2007. Silicone gel implants in breast augmentation and reconstruction. Ann Plast Surg 59: 581-590.

GANCEDO M, RUIZ-CORRO L, SALAZAR-MONTES A, RINCON AR AND ARMENDARIZ-BORUNDA J. 2008. Pirfenidone prevents capsular contracture after mammary implantation. Aesth Plast Surg 32: 32-40.

GERSUNY R. 1980. The classic reprint. Concerning a subcutaneous prosthesis: Robert Gersuny. (Uber eine subcutane Prothese. Zeitschrift f. Heilkunde Wien u Leipzig 21:199, 1900.). Translated from the German by Miss Rita Euerle. Plast Reconstr Surg 65: 525-527.

HAKELIUS L AND OHLSEN L. 1997. Tendency to capsular contracture around smooth and textured gel-filled silicone mammary implants: A five-year follow-up. Plast Reconstr Surg 100: 1566.

HANDEL N, JENSEN JA, BLACK Q, WAISMAN JR AND SILVERSTEIN MJ. 1995. The fate of breast implants: A critical analysis of complications and outcomes. Plast Reconstr Surg 96: 1521.

HARRIS HI. 1961. Research in plastic implants. Their use in augmentation for amastia or hypomastia. J Int Coll Surg 35: 630-643.

HENRIKSEN TF, FRYZEK JP, HOLMICH LR, MCLAUGHLIN JK, KJOLLER K, HOYER AP, OLSEN JH AND FRIIS S. 2005. Surgical intervention and capsular contracture after breast augmentation: a prospective study of risk factors. Ann Plast Surg 54: 343-351.

HESTER TR JR, NAHAI F, BOSTWICK J AND CUKIC J. 1988. A 5-year experience with polyurethane-covered mammary prostheses for treatment of capsular contracture, primary augmentation mammoplasty, and breast reconstruction. Clin Plast Surg 15: 569-585.

HESTER TR JR, TEBBETTS JB AND MAXWELL GP. 2001. The polyurethane-covered mammary prosthesis: facts and fiction (II): a look back and a "peek" ahead. Clin Plast Surg 28: 579-586.

IBRAHIM CANTER H, KONAS E, BOZDOGAN O, VARGEL I, OZBATIR B, ONER F AND ERK Y. 2007. Effect of slow-release 5-Fluorouracil on capsule formation around silicone breast implants: an experimental study with mice. Aesth Plast Surg 31: 674-679.

IMBER G, SCHAWAGER RG, GUTHTIE RH AND GRAY GF. 1974. Fibrous Capsula formation after subcutaneous implantation of synthetic materials in experimental animals. Plast Reconstr Surg 54: 183.

KJOLLER K ET AL. 2001. Capsular contracture after cosmetic breast implant surgery in Denmark. Ann Plast Surg 47: 359-366.

KOSSOVSKY N, HEGGERS JP, PARSONS RW AND ROBSON MC. 1984. Acceleration of capsule formation around silicone implants by infection in a guinea pig model. Plast Reconstr Surg 73: 91-98.

KSANDER GA, VISTNES LM AND KOSEK J. 1981. Effect of implant location on compressibility and capsule formation around miniprostheses in rats, and experimental capsule contracture. Ann Plast Surg 6: 182-193.

LALARDRIE JP AND MOULY R. 1978. History of mammaplasty. Aesth Plast Surg 2: 167-176.

LEE SD, YI MH, KIM DW, LEE Y, CHOI Y AND OH SH. 2014. The effect of botulinum neurotoxin type A on capsule formation around silicone implants: the in vivo and in vitro study. Int Wound J 13(1): 65-71.

LEMPERLE G AND EXNER K. 1993. Effect of cortisone on capsular contracture in double-lumen breast implants: ten years' experience. Aesth Plast Surg 17: 317-323.

LILLA JAAND VISTES LM. 1976. Long study od reactions to various silicone breast implants in rabbits. Plast Reconstr Surg 57: 668 . 
LYRAS I. 1993. Tissue reaction to rough and smooth silicone implants (A comparative and analytical experimental study in rats. Rev Soc Bras Cir Plast 8: 31-41.

MARQUES M, BROWN S, CORREIA-SA I, MN DSC, RODRIGUES-PEREIRA P, GONCALVES-RODRIGUES AAND AMARANTE J. 2012. The impact of triamcinolone acetonide in early breast capsule formation in a rabbit model. Aesth Plast Surg 36: 986-994.

MAXWELL GP AND GABRIEL A. 2009. The evolution of breast implants. Clinics in plastic surgery 36: 1-13.

MENDES PR, BINS-ELY J, LIMA EA, VASCONCELLOS ZA, D'ACAMPORA AJ AND NEVES RD. 2008. Histological study on acute inflammatory reaction to polyurethane-coated silicone implants in rats. Acta Cir Bras 23: 93-101.

MINAMI E, KOH IH, FERREIRA JC, WAITZBERG AF, CHIFFERI V, ROSEWICK TF, PEREIRA MD, SALDIVA PH AND DE FIGUEIREDO LF. 2006. The composition and behavior of capsules around smooth and textured breast implants in pigs. Plast Reconstr Surg 118: 874-884.

MOREIRA M, FAGUNDES DJ, DE JESUS SIMOES M, DE OLIVEIRA MC, DOS SANTOS PREVIDELLI IT AND MOREIRA AC. 2009. Zafirlukast pocket delivery impairs the capsule healing around textured implants in rats. Aesth Plast Surg 33: 90-97.

MOYER HR, GHAZI BH AND LOSKEN A. 2012. The effect of silicone gel bleed on capsular contracture: a generational study. Plast Reconstr Surg 130: 793-800.

NETSCHER DT. 2004. Subclinical infection in breast capsules. Plast Reconstr Surg 114: 818-820.

PARK SO, HAN J, MINN KW AND JIN US. 2013. Prevention of capsular contracture with Guardix-SG((R)) after silicone implant insertion. Aesth Plast Surg 37: 543-548.

PETERS CR, SHAW TE AND RAJU DR. 1980. The influence of vitamin $\mathrm{E}$ on capsule formation and contracture aroud silicone implants. Ann Plast Surg 5: 347-352.

PICHA GJ AND GOLDSTEIN JA. 1991. Analysis of the softtissue response to components used in the manufacture of breast implants: rat animal model. Plast Reconstr Surg 87: 490-500.

PICHA GJ, GOLDSTEIN JAAND STOHR E. 1990. Natural-Y Meme polyurethane versus smooth silicone: analysis of the soft-tissue interaction from 3 days to 1 year in the rat animal model. Plast Reconstr Surg 85: 903-916.

PITANGUY I. 1991. Estudo retrospectivo das aplicações clínicas da prótese de silicone gel revestida com poliuretano. Bol Acad Nac Med 151: 67-72.

POEPPL N, SCHREML S, LICHTENEGER F, LENICH A, EISENMANN-KLEIN M AND PRANTL L. 2007. Does the surface structure of implants have an impact on the formation of a capsular contracture? Aesth Plast Surg 31: 133-139.
POLLOCK H. 1997. Breast capsular contracture. Plast Reconstr Surg 100: 1619-1620.

PUCKETT CL, CROLL GH, REICHEL CA AND CONCANNON MJ. 1987. A critical look at capsule contracture in subglandular versus subpectoral mammary augmentation. Aesth Plast Surg 11: 23-28.

REBELLO C. 1996. Mamaplastia de aumento: algumas considerações científicas sobre a validade do emprego dos implantes de gel de silicone. Rev Bras Cir 86(5): 261-283.

RIEGER UM, MESINA J, KALBERMATTEN DF, HAUG M, FREY HP, PICO R, FREI R, PIERER G, LUSCHER NJ AND TRAMPUZ A. 2013. Bacterial biofilms and capsular contracture in patients with breast implants. Brit J Surg 100: 768-774.

ROHRICH RJ, KENKEL JM AND ADAMS WP. 1999. Preventing capsular contracture in breast augmentation: in search of the Holy Grail. Plast Reconstr Surg 103: 17591760 .

RUBIN LR. 1951. Polyethylene--a three year study. Plast Reconstr Surg 7: 131-142.

SANK A, CHALABIAN-BALIOZIAN J, ERTL D, SHERMAN R, NIMNI M AND TUAN TL. 1993. Cellular responses to silicone and polyurethane prosthetic surfaces. J Surg Res 54: 12-20.

SANTERE JP, WODHOUSE K, LAROCHE G AND LABOW RS. 2005. Understanding the biodegradation of polyurethanes: From classical implants to tissue engineering materials. Biomaterials 26: 7457-7470.

SHAH Z, LEHMAN JA AND TAN J. 1981. Does infection play a role in breast capsular contracture? Plast Reconstr Surg 68: 34-38.

SHIN KC, CHUNG KI, PARK BY, KIM HK, KIM WS, BAE TH AND KIM MK. 2013. The effect of antiadhesion agent on peri-implant capsular formation in rabbits. Ann Plast Surg 71: 600-604.

SMAHEL J, SCHNEIDER K AND DONSKI P. 1977. Bizarre implants for augmentation mammaplasty: long term human reaction to polyethylene strips. Brit J Plast Surg 30: 287-290.

SPEAR SL, BULAN EJ AND VENTURI ML. 2006. Breast augmentation. Plast Reconstr Surg 118: 188S-196S.

SPEAR SL, ELMARAGHY M AND HESS C. 2000. Textured-surface saline-filled silicone breast implants for augmentation mammaplasty. Plast Reconstr Surg 105: 1542-1552.

SPEAR SL, PARIKH PM AND GOLDSTEIN JA. 2009. History of breast implants and the food and drug administration. Clin Plast Surg 36: 15-21.

STEIERT AE, BOYCE M AND SORG H. 2013. Capsular contracture by silicone breast implants: possible causes, biocompatibility, and prophylactic strategies. Medical devices (Auckland, NZ) 6: 211-218.

SUKHOVA I, MULLER D, EISENMANN-KLEIN M, MACHENS HG AND SCHANTZ JT. 2012. Quo vadis? 
Breast implants--current trends and new concepts. Handchir Mikrochir Plast Chir 44: 240-253.

TANG L, JENNINGS TA AND EATON JW. 1998. Mast cells mediate acute inflammatory responses to implanted biomaterials. Proceedings of the PNAS 95: 8841-8846.

THOREK M. 1942. Amastia, hypomastia, and inequality of the breasts. In: Plastic surgery of the breast and abdominal wall. Springfield (IL): Thomas. In: Plastic surgery of the breast and abdominal wall, p. 369-386.

THUESEN B, SIIM E, CHRISTENSEN L AND SCHRODER M. 1995. Capsular contracture after breast reconstruction with the tissue expansion technique. A comparison of smooth and textured silicone breast prostheses. Scand J Plast Reconstr Surg Hand Surg 29: 9-13.

UZUNISMAIL A, PERK C, FINDIK H, BEYHAN G AND DINCLER M. 2008. Effect of a fascial tissue interface on silicone implant capsule formation--a preliminary experimental study. JPRAS 61: 1199-1204.

VAN HEERDEN J, TURNER M, HOFFMANN D AND MOOLMAN J. 2009. Antimicrobial coating agents: can biofilm formation on a breast implant be prevented? JPRAS 62: 610-617.
VIEIRA VJ, D'ACAMPORA AJ, MARCOS AB, DI GIUNTA G, DE VASCONCELLOS ZA, BINS-ELY J, D'ECA NEVES R AND FIGUEIREDO CP. 2010. Vascular endothelial growth factor overexpression positively modulates the characteristics of periprosthetic tissue of polyurethane-coated silicone breast implant in rats. Plast Reconstr Surg 126: 1899-1910.

WONG CH, SAMUEL M, TAN BK AND SONG C. 2006. Capsular contracture in subglandular breast augmentation with textured versus smooth breast implants: a systematic review. Plast Reconstr Surg 118: 1224-1236.

YOUNG VL AND WATSON ME. 2001. Breast implant research: where we have been, where we are, where we need to go. Clin Plast Surg 28: 451-483.

ZIMMAN OA. 2007. A rabbit model for capsular contracture: development and clinical implications. Plast Reconstr Surg 119: 1955-1956.

ZIMMAN OA, TOBLLI J, STELLA I, FERDER M, FERDER L AND INSERRA F. 2007. The effects of angiotensinconverting-enzyme inhibitors on the fibrous envelope around mammary implants. Plast Reconstr Surg 120: 2025-2033. 